\title{
A systematic review and meta-analysis of the role of Helicobacter pylori eradication in preventing gastric cancer
}

\author{
Theodore Rokkas ${ }^{a}$, Androniki Rokkab ${ }^{\text {, Piero Portincasa }}{ }^{\mathrm{b}}$ \\ Henry Dunant Hospital, Athens, Greece; Aldo Moro University, Bari Medical School, Bari, Italy
}

\begin{abstract}
Background Increasing evidence has suggested that Helicobacter pylori (H. pylori) eradication might prevent the development of gastric cancer (GC). This systematic review and meta-analysis aimed to better explore the role of $H$. pylori eradication in preventing GC, with particular reference to patients with precancerous lesions at baseline histology.

Methods Searches for human studies were performed through October 2016 and risk ratios (RRs), were obtained. Heterogeneity between studies was estimated using the Cochran Q test and $I^{2}$ values, whereas the possibility of publication bias was estimated with funnel plots. Additionally, we performed subgroup and sensitivity analyses.

Results In 26 studies suitable for meta-analysis (10 randomized controlled trials and 16 cohort studies) 52,363 subjects were included. The risk of GC among patients in whom H. pylori was successfully eradicated was significantly lower than that among controls: pooled RRs [95\% CI] $0.56[0.48-0.66], Z=-7.27, P=0.00001$. This finding applied separately for randomized controlled trials $(0.65[0.51-0.84], \mathrm{Z}=-3.33, \mathrm{P}=0.0009)$ and for cohort studies $(0.51$ [0.42-0.62], $\mathrm{Z}=-6.63$, $\mathrm{P}=0.00001)$. Concerning $H$. pylori eradication in patients with precancerous lesions, subgroup analyses showed that patients with non-atrophic or atrophic gastritis benefited from $H$. pylori eradication for the risk of GC development, whereas those with intestinal metaplasia or dysplasia did not.
\end{abstract}

Conclusion H. pylori eradication is associated with a significantly lower risk of GC; this finding has significant implications for the prevention of this cancer. The benefit is maximized when H. pylori eradication is applied at early stages of the infection.

Keywords $H$. pylori, eradication, gastric cancer, prevention, meta-analysis

Ann Gastroenterol 2017; 30 (4): 1-10

\section{Introduction}

Despite a decline of gastric cancer (GC) in many countries in the developed world, GC remains among the most common causes of cancer death globally [1]. In fact, there is an increase in global mortality from the disease due to population growth and increasing life expectancy in the developing world [2]. Two

${ }^{\mathrm{a}}$ Gastroenterology Clinic, Henry Dunant Hospital, Athens, Greece (Theodore Rokkas); 'Department of Internal Medicine, "Aldo Moro" University, Bari Medical School, Bari, Italy (Androniki Rokka, Piero Pontincasa)

\section{Conflict of Interest: None}

Correspondence to: Theodore Rokkas MD, PhD, FACG, AGAF, FEBG, 192b Alexandras Ave., Athens 11521, Greece, e-mail: sakkor@otenet.gr

Received 13 January 2017; accepted 4 March 2017; published online 7 April 2017

DOI: https://doi.org/10.20524/aog.2017.0144 major types are evident: The intestinal and the diffuse type. The intestinal type, the more common variant, shows a strong association with Helicobacter pylori (H. pylori) infection, as well as other factors such as cigarette smoking and diet (salted foods). The diffuse type is less common and is attributed to host-factor influences, such as mutations in the E-cadherin gene.

H. pylori infection affects approximately $50 \%$ of the global population [3] and it is the principal trigger of gastric carcinogenesis. It is believed to predispose to GC by inducing precancerous changes, i.e., atrophic gastritis (AG) and intestinal metaplasia (IM) [4,5]. There is evidence that subjects infected by $H$. pylori were between three and six times more prone to develop GC than uninfected controls [6-8]. These data were taken into account by the International Agency for Research on Cancer, which declared H. pylori as a class I human carcinogen [9]. Eradication of H. pylori can result in amelioration of gastric inflammation, halt the progression of gastric mucosal damage, prevent further $H$. pylori-induced DNA damage, improve gastric acid secretion, and restore the microbiome toward normal [10]. Because we can treat 
H. pylori with a course of antibiotic treatment, identifying and treating $H$. pylori infection could represent a strategy for reducing the disease burden of GC [11]. Thus, an earlier meta-analysis [12] that pooled randomized controlled trials (RCTs) conducted in asymptomatic infected individuals reported that $H$. pylori treatment could reduce the risk of GC in Asians.

As more data concerning the relationship of $H$. pylori treatment and GC prevention have become available from recent studies, we undertook the present meta-analysis to update and better define this relationship. We gave particular attention to studies that examined the role of $H$. pylori eradication in reducing the cancer risk in patients with precancerous lesions at baseline histology, i.e., AG, IM, and dysplasia (DYS).

\section{Materials and methods}

\section{Study identification and extraction of data}

The three authors performed extensive PubMed, MEDLINE and Embase database medical literature searches for human studies through October 2016, using suitable key words ("stomach neoplasms" [MeSH Terms] OR ("stomach"[All Fields] AND "neoplasms"[All Fields]) OR "stomach neoplasms"[All Fields] OR ("gastric"[All Fields] AND "cancer"[All Fields]) OR "gastric cancer"[All Fields]) AND ("helicobacter pylori" [MeSH Terms] OR ("helicobacter" [All Fields] AND "pylori" [All Fields]) OR "helicobacter pylori" [All Fields] OR "h pylori" [All Fields]) AND (("therapy" [Subheading] OR "therapy" [All Fields] OR "treatment" [All Fields] OR "therapeutics" [MeSH Terms] OR "therapeutics" [All Fields]) OR eradication [All Fields]) AND ("prevention and control"[Subheading] OR ("prevention" [All Fields] AND "control" [All Fields]) OR "prevention and control" [All Fields] OR "prevention" [All Fields]). A full manual search of all review articles, recently published editorials and retrieved original studies was also performed. Two of the authors (TR and PP) independently extracted data from suitable studies using a standard form. Any disagreement was settled by further discussion. The meta-analysis was performed in agreement with PRISMA [13].

\section{Selection criteria}

Inclusion and exclusion criteria were defined prior to the literature search. Hence, the following criteria had to be met for studies to be included in this meta-analysis: 1) published as full articles or abstracts; 2) written in English; and 3) randomized controlled trials (RCTs) or observational studies with data on the association of $H$. pylori eradication and GC prevention. Exclusion criteria were the following: 1) studies not meeting the inclusion criteria; 2) studies without data for retrieval; 3) duplicate studies; and 4) the less informative publication of two on the same study.

\section{Statistical analysis}

Authors' agreement on study selection was measured by the $\kappa$ coefficient. The pooled risk ratio (RR) and the $95 \%$ confidence interval (CI) were calculated and results of individual studies were compared by employing the Mantel-Haenszel method (fixed-effects model) [14] or the DerSimonian and Laird method (random-effects model) [15]. Forest plots were constructed for the visual display of RRs of individual studies. Heterogeneity between studies was measured with the Cochran $\mathrm{Q}$ test [16] and was judged significant when the Q test had a P-value of less than $0.10[17,18]$. In addition, the $I^{2}$ statistic was employed to estimate the rate of inconsistency in individual studies that could not be interpreted by chance [19]. When statistically significant heterogeneity was not present, pooled RRs (95\% CI) were calculated using the fixed-effects model. If significant heterogeneity was present, pooled RRs (95\% CI) were calculated using the random-effects model [17-19]. We also used cumulative meta-analysis to explore whether the association between $H$. pylori eradication and GC remained steady [18]. The Comprehensive Meta-Analysis software, version 2 (BIOSTAT INC., Englewood, NJ, USA), was used in all calculations throughout this meta-analysis.

\section{Sensitivity analyses and publication bias}

In case of significant heterogeneity, except for the randomeffects model, sensitivity analyses were employed to judge the consistency of the results. Thus, to explore any significant influence of single studies on the pooled RR results, we performed the exclusion method by repeating the meta-analysis after excluding single studies one at a time [18]. Furthermore, as different populations and study designs may incorporate various

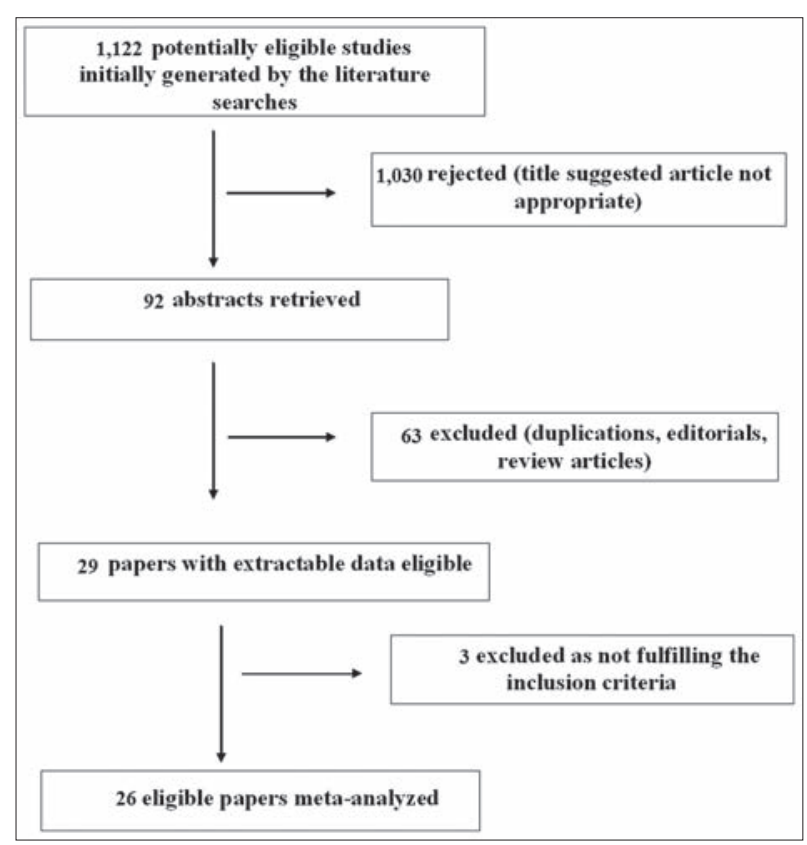

Figure 1 Flow diagram of the studies identified in this meta-analysis 


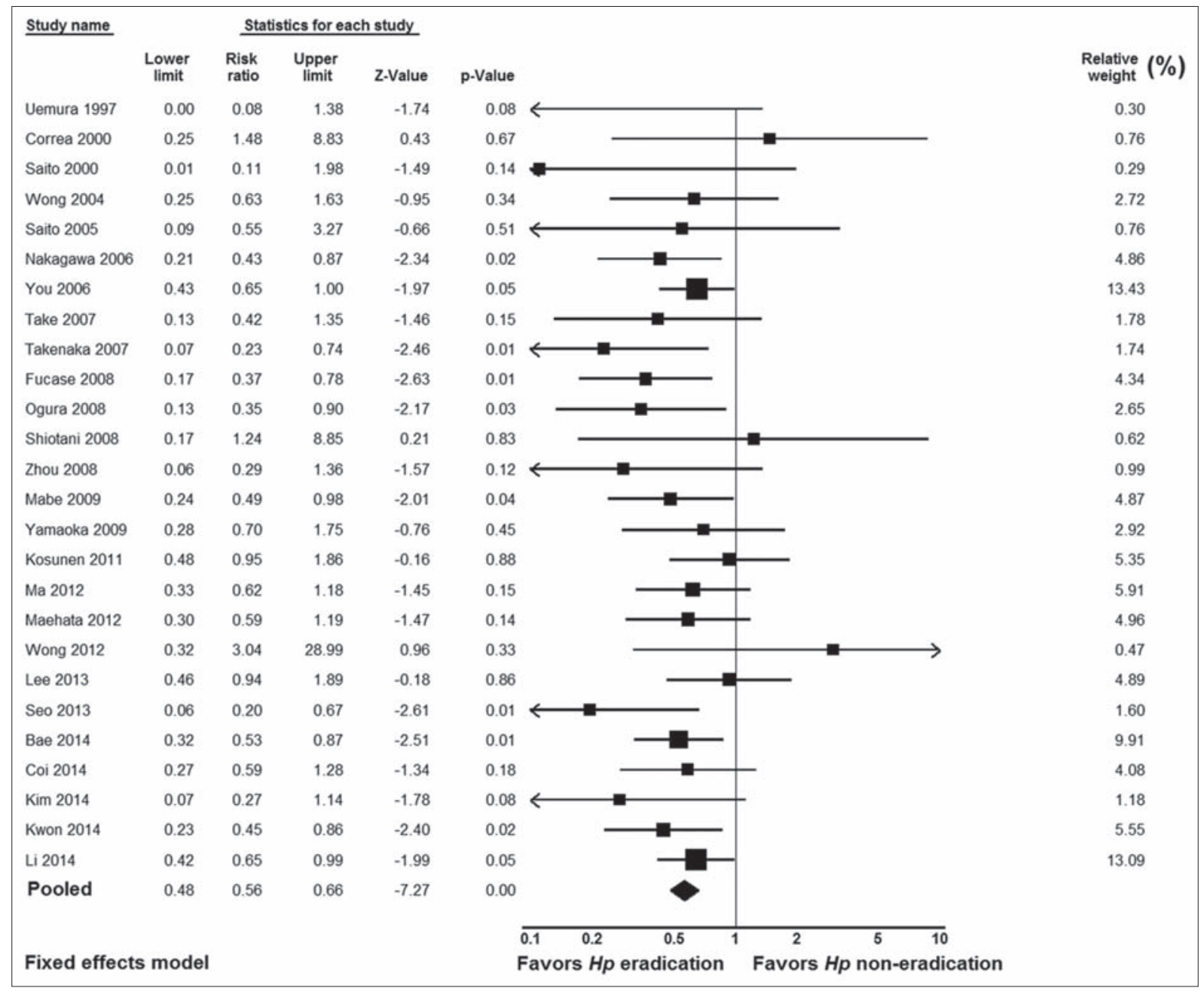

Figure 2 Forest plot showing individual and pooled risk ratios and 95\% confidence intervals in studies comparing gastric cancer risk in Helicobacter pylori $(\mathrm{Hp})$-eradicated patients and in controls

biases, we employed subgroup analyses by stratifying all factors that could influence the overall results. In addition, we further explored possible heterogeneity using meta-regression analyses (methods of moments) [20]. The possibility of publication bias was examined by constructing funnel plots. These were constructed by plotting the log RRs vs. Standard Error (SE) of individual studies $[20,21]$. Their symmetry was measured by Egger's regression test and the Begg and Mazumdar adjusted rank correlation test $[22,23]$. The adjustment for publication bias, i.e., calculation of the number of studies missing from the meta-analysis, was achieved by using the nonparametric "trim and fill” rank-based method of Duval and Tweedie [24].

\section{Results}

\section{Descriptive assessment and characteristics of the studies}

Agreement between the authors regarding the selection of suitable articles and data extraction was high: $\kappa=0.93,95 \%$
CI 0.83-1. A flow chart explaining the study selection is shown in Fig. 1. Of the 1122 titles initially found by the literature searches, 26 studies were found suitable for meta-analysis, 8 RCTs and 18 observational (cohort) studies [25-50]. There were 24 studies from Far East countries (13 from Japan, 5 from China, 5 from Korea, 1 from Taiwan), 1 from Colombia and 1 from Finland. Table 1 shows the characteristics of the 26 eligible studies for meta-analysis.

\section{GC risk in $H$. pylori treated patients and non-treated (controls)}

A total of 22,619 patients and 29,744 controls were included in the 26 meta-analysis studies. There was no significant heterogeneity in the included studies: $\mathrm{Q}=23.09, \mathrm{df}(\mathrm{Q})=25$, $I^{2}=0 \%, \mathrm{P}=0.57$. Therefore, we applied the fixed-effects model, which yielded significant results: i.e., pooled $\mathrm{RR}$ result 0.56 , 95\% CI 0.48-0.66, test for overall effect $\mathrm{Z}=-7.27, \mathrm{P}=0.00001$ (Fig. 2). No publication bias was found, as seen in the funnel plot and its symmetry calculation: $\mathrm{P}=0.11$ by adjusted rank correlation test and 0.14 by Egger's regression test (Fig. 3). 
Table 1 The main characteristics of the studies included in the meta-analysis

\begin{tabular}{|c|c|c|c|c|c|c|c|c|c|}
\hline \multirow[t]{2}{*}{$1^{\text {st }}$ author (Ref.) } & \multirow[t]{2}{*}{ Year } & \multirow[t]{2}{*}{ Region } & \multirow[t]{2}{*}{$\begin{array}{l}\text { Study } \\
\text { design }\end{array}$} & \multirow[t]{2}{*}{$\begin{array}{l}\text { Publication } \\
\text { type }\end{array}$} & \multirow[t]{2}{*}{$\begin{array}{c}\text { Follow up mean } \\
\text { duration (yrs) }\end{array}$} & \multicolumn{2}{|c|}{ Eradication group } & \multicolumn{2}{|c|}{$\begin{array}{l}\text { Control group } \\
\text { (Non-eradicated) }\end{array}$} \\
\hline & & & & & & $\begin{array}{c}\text { Gastric } \\
\text { cancer }(\mathrm{n})\end{array}$ & Total (n) & $\begin{array}{c}\text { Gastric } \\
\text { cancer }(\mathrm{n})\end{array}$ & Total (n) \\
\hline Uemura [25] & 1997 & Japan & Cohort & $\begin{array}{l}\text { Published } \\
\text { paper }\end{array}$ & 4 & 0 & 65 & 6 & 67 \\
\hline Correa[26] & 2000 & Colombia & $\begin{array}{l}\text { Randomized } \\
\text { control trial }\end{array}$ & $\begin{array}{l}\text { Published } \\
\text { paper }\end{array}$ & 6 & 3 & 491 & 2 & 485 \\
\hline Saito [27] & 2000 & Japan & Cohort & $\begin{array}{l}\text { Published } \\
\text { paper }\end{array}$ & 2 & 0 & 32 & 4 & 32 \\
\hline Wong [28] & 2004 & China & $\begin{array}{l}\text { Randomized } \\
\text { control trial }\end{array}$ & $\begin{array}{l}\text { Published } \\
\text { paper }\end{array}$ & 7.5 & 7 & 817 & 11 & 813 \\
\hline Saito [29] & 2005 & Japan & $\begin{array}{l}\text { Randomized } \\
\text { control trial }\end{array}$ & Abstract & 4 & 2 & 379 & 3 & 313 \\
\hline Nakagawa [30] & 2006 & Japan & Cohort & $\begin{array}{l}\text { Published } \\
\text { paper }\end{array}$ & 2 & 8 & 356 & 129 & 2,469 \\
\hline You [31] & 2006 & Japan & $\begin{array}{l}\text { Randomized } \\
\text { control trial }\end{array}$ & $\begin{array}{l}\text { Published } \\
\text { paper }\end{array}$ & 14.6 & 34 & 1,130 & 52 & 1,128 \\
\hline Take [32] & 2007 & Japan & Cohort & $\begin{array}{l}\text { Published } \\
\text { paper }\end{array}$ & 3.9 & 9 & 953 & 4 & 178 \\
\hline Takenaka [33] & 2007 & Japan & Cohort & $\begin{array}{l}\text { Published } \\
\text { paper }\end{array}$ & 3.2 & 6 & 1,519 & 5 & 288 \\
\hline Fucase [34] & 2008 & Japan & $\begin{array}{l}\text { Randomized } \\
\text { control trial }\end{array}$ & $\begin{array}{l}\text { Published } \\
\text { paper }\end{array}$ & 3 & 9 & 255 & 24 & 250 \\
\hline Ogura [35] & 2008 & Japan & Cohort & $\begin{array}{l}\text { Published } \\
\text { paper }\end{array}$ & 3.2 & 6 & 404 & 13 & 304 \\
\hline Shiotani [36] & 2008 & Japan & Cohort & $\begin{array}{l}\text { Published } \\
\text { paper }\end{array}$ & 2.7 & 4 & 41 & 3 & 6 \\
\hline Zhou[37] & 2008 & China & $\begin{array}{l}\text { Randomized } \\
\text { control trial }\end{array}$ & Abstract & 10 & 2 & 276 & 7 & 276 \\
\hline Mabe[38] & 2009 & Japan & Cohort & $\begin{array}{l}\text { Published } \\
\text { paper }\end{array}$ & 5.6 & 47 & 3,781 & 9 & 352 \\
\hline Yanaoka[39] & 2009 & Japan & Cohort & $\begin{array}{l}\text { Published } \\
\text { paper }\end{array}$ & 9.3 & 5 & 473 & 55 & 3656 \\
\hline Kosunen [40] & 2011 & Finland & Cohort & $\begin{array}{l}\text { Published } \\
\text { paper }\end{array}$ & 10 & 11 & 3,650 & 37 & 11,638 \\
\hline Ma [41] & 2012 & China & $\begin{array}{l}\text { Randomized } \\
\text { control trial }\end{array}$ & $\begin{array}{l}\text { Published } \\
\text { paper }\end{array}$ & 14.7 & 15 & 1,130 & 24 & 1,128 \\
\hline Maehata [42] & 2012 & Japan & Cohort & $\begin{array}{l}\text { Published } \\
\text { paper }\end{array}$ & 3 & 15 & 177 & 13 & 91 \\
\hline Wong [43] & 2012 & China & $\begin{array}{l}\text { Randomized } \\
\text { control trial }\end{array}$ & $\begin{array}{l}\text { Published } \\
\text { paper }\end{array}$ & 5 & 3 & 255 & 1 & 258 \\
\hline Seo $[44]$ & 2013 & Korea & Cohort & $\begin{array}{l}\text { Published } \\
\text { paper }\end{array}$ & 2 & 4 & 41 & 3 & 6 \\
\hline Bae [45] & 2014 & Korea & Cohort & $\begin{array}{l}\text { Published } \\
\text { paper }\end{array}$ & 5 & 34 & 485 & 24 & 182 \\
\hline Choi [46] & 2014 & Korea & $\begin{array}{l}\text { Randomized } \\
\text { control trial }\end{array}$ & $\begin{array}{l}\text { Published } \\
\text { paper }\end{array}$ & 3 & 10 & 439 & 17 & 441 \\
\hline Kim [47] & 2014 & Korea & Cohort & $\begin{array}{l}\text { Published } \\
\text { paper }\end{array}$ & 4.3 & 2 & 49 & 16 & 107 \\
\hline
\end{tabular}


Table 1 Continued..

\begin{tabular}{|c|c|c|c|c|c|c|c|c|c|}
\hline \multirow[t]{2}{*}{$1^{\text {st }}$ author (Ref.) } & \multirow[t]{2}{*}{ Year } & \multirow[t]{2}{*}{ Region } & \multirow[t]{2}{*}{$\begin{array}{l}\text { Study } \\
\text { design }\end{array}$} & \multirow[t]{2}{*}{$\begin{array}{l}\text { Publication } \\
\text { type }\end{array}$} & \multirow[t]{2}{*}{$\begin{array}{c}\text { Follow up mean } \\
\text { duration (yrs) }\end{array}$} & \multicolumn{2}{|c|}{ Eradication group } & \multicolumn{2}{|c|}{$\begin{array}{l}\text { Control group } \\
\text { (Non-eradicated) }\end{array}$} \\
\hline & & & & & & $\begin{array}{c}\text { Gastric } \\
\text { cancer (n) }\end{array}$ & Total (n) & $\begin{array}{c}\text { Gastric } \\
\text { cancer (n) }\end{array}$ & Total (n) \\
\hline Kwon [48] & 2014 & Korea & Cohort & $\begin{array}{l}\text { Published } \\
\text { paper }\end{array}$ & 3.2 & 18 & 214 & 13 & 69 \\
\hline Lee [49] & 2014 & Taiwan & Cohort & $\begin{array}{l}\text { Published } \\
\text { paper }\end{array}$ & 5 & 15 & 4,121 & 16 & 4,121 \\
\hline $\operatorname{Li}[50]$ & 2014 & China & $\begin{array}{l}\text { Randomized } \\
\text { control trial }\end{array}$ & $\begin{array}{l}\text { Published } \\
\text { paper }\end{array}$ & 15 & 51 & 1,086 & 33 & 1,086 \\
\hline Total & & & & & & 320 & 22,619 & 524 & 29,744 \\
\hline
\end{tabular}

Table 2 Sub-group analyses by stratifying the data according to study design, geographical region and kind of prevention (primary vs. secondary)

\begin{tabular}{|c|c|c|c|c|c|c|c|}
\hline \multicolumn{4}{|l|}{ Core analysis } & \multicolumn{4}{|c|}{ Heterogeneity } \\
\hline Sub-groups (n studies) & RR (95\% CI) & $\mathrm{Z}$ value & $\mathrm{P}$ value & $\mathrm{Q}$ value & $\mathrm{Df}(\mathrm{Q})$ & $\mathrm{I}^{2} \%$ & $P$ value \\
\hline \multicolumn{8}{|l|}{ Study design } \\
\hline $\operatorname{RCTs}(\mathrm{n}=8)$ & $0.65(0.51-0.84)$ & -3.33 & 0.0009 & 3.73 & 7 & 0 & 0.81 \\
\hline Cohort $(n=18)$ & $0.51(0.42-0.62)$ & -6.63 & 0.00001 & 17.2 & 17 & 11.8 & 0.44 \\
\hline \multicolumn{8}{|l|}{ Geographical region } \\
\hline Colombia $(\mathrm{n}=1)$ & $1.48(0.25-8.83)$ & 0.43 & 0.67 & - & - & - & - \\
\hline Finland $(\mathrm{n}=1)$ & $0.95(0.48-1.86)$ & -0.16 & 0.88 & - & - & - & 1 \\
\hline Far East $(\mathrm{n}=24)$ & $0.54(0.46-0.63)$ & -7.51 & 0.000001 & 19.42 & 23 & 0 & 0.68 \\
\hline \multicolumn{8}{|c|}{ Kind of prevention (primary vs. secondary) } \\
\hline Primary $(n=16)$ & $0.63(0.52-0.77)$ & -4.62 & 0.000004 & 13.23 & 15 & 0 & 0.58 \\
\hline Secondary $(n=10)$ & $0.46(0.36-0.60)$ & -5.91 & 0.000001 & 6.44 & 9 & 0 & 0.69 \\
\hline
\end{tabular}

RR, risk ratio; CI, confidence interval; $R C T$, randomized control trial

\section{Subgroup and sensitivity analyses}

We performed subgroup analyses to examine whether the significant result found for all 26 studies would apply separately when the data were stratified according to study design (i.e., RCTs vs. cohort studies), geographical region, and kind of prevention, i.e., primary vs. secondary, according to whether or not early GC endoscopic resection was performed before $H$. pylori treatment was given to prevent the development of metachronous cancer. The results of these subgroup analyses are shown in Table 2. There were significant results for both groups of study design: i.e., 0.65 (0.51-0.84), $\mathrm{Z}=-3.33, \mathrm{P}=0.0009$ for RCTs, and $0.51(0.42$ $0.62), Z=-6.63, P=0.00001$ for cohort studies. Concerning geographical region, there were significant results for the Far East studies (0.54 [0.46-0.63], $\mathrm{Z}=-7.51, \mathrm{P}=0.000001)$, whereas the results were not significant for the American study from Colombia (1.48 [0.25-8.83], $\mathrm{Z}=-0.43, \mathrm{P}=0.67)$ or the European study from Finland (0. 95 [0.48-1.86], $Z=-0.16$, $\mathrm{P}=0.88)$. There were significant results for both primary $(0.63$ [0.52-0.77], $\mathrm{Z}=-4.62, \mathrm{P}=0.000004)$ and secondary prevention

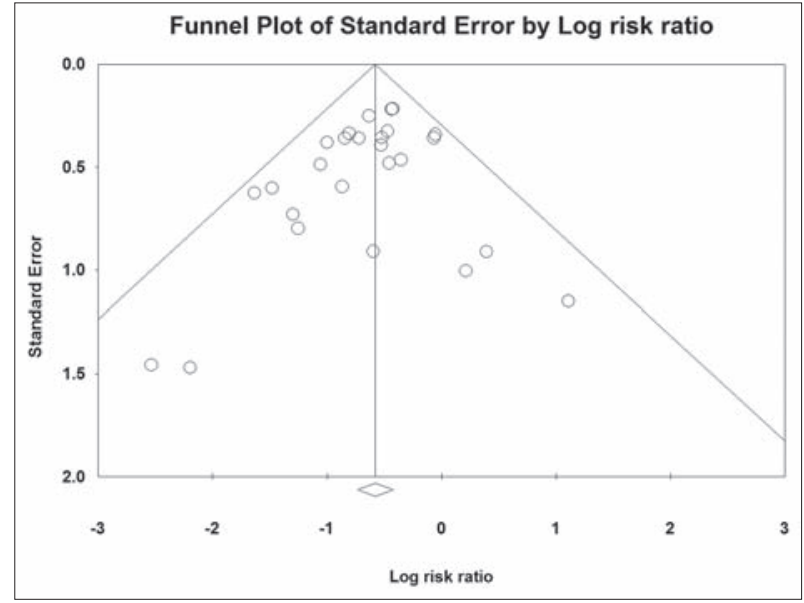

Figure 3 Funnel plot of all studies included in the meta-analysis. There is no evidence of publication bias ( $\mathrm{P}=0.11$ by Begg and Mazumdar adjusted rank correlation test and 0.14 by Egger's regression test)

(0.46 [0.36-0.60], $\mathrm{Z}=-5.91, \mathrm{P}=0.000001)$. Additionally, more sensitivity analyses were utilized to detect the presence of 


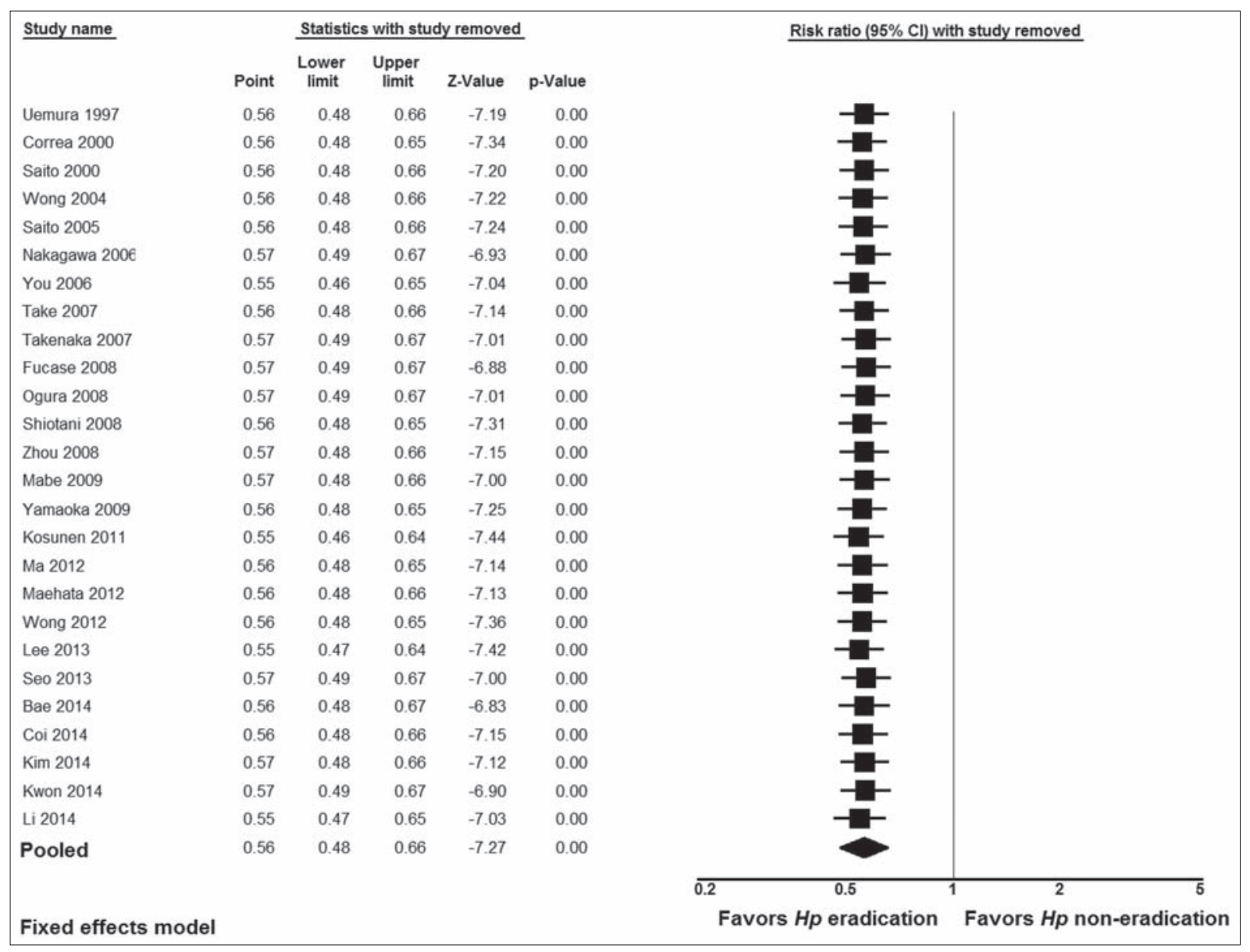

Figure 4 Exclusion sensitivity plot showing the effect of exclusion of any study on the magnitude of the summary estimate

any biases related to included populations and different study designs. The exclusion of any study did not alter the summary results substantially (Fig. 4). Furthermore, the results of the cumulative meta-analysis did not change over the years (Fig. 5). In addition, the meta-regression analyses showed no significant results for publication year $(\mathrm{Z}=0.67$, $\mathrm{P}=0.49$ ), but significant results for mean duration follow up ( $Z=1.96 .57, P=0.049)$ (Fig. 6). The latter was expected as more cancers were noted in subjects who had longer duration of follow up.

\section{GC risk according to baseline histology}

Five studies [26,28,31,43,46] examined the GC risk according to baseline histology and the results are shown in Fig. 7. These studies stratified baseline histology into two groups: i.e., a group of subjects with chronic non-AG (NAG) or AG, and a group of subjects with IM or DYS. The RR [95\% CI] was significant in the NAG/AG group $(0.28$ [0.08-0.96], $\mathrm{Z}=-2.03, \mathrm{P}=0.04)$, but not in the IM/DYS group (0.84 [0.55-1.28], $\mathrm{Z}=-0.83, \mathrm{P}=0.41)$.

\section{Discussion}

Despite the decline in its incidence in recent decades, GC remains a major health concern in many parts of the world. The development of GC constitutes a complex cascade of events, characterized mainly by interactions between $H$. pylori infection, host factors and environmental influences, such as diet [51]. Indeed, H. pylori plays a crucial role in this process, as most non-cardia GCs develop from $H$. pylori-infected mucosa [52]. In the gastric mucosa, $H$. pylori initiates a cascade of events, which may lead to chronic AG and then to IM, DYS, and finally carcinoma [53]. Such a proposal is supported by a substantial number of studies performed in countries with a high incidence of GC. Indeed, in these countries H. pylori eradication has been proposed as a potentially important primary preventive strategy to reduce GC incidence. The results of this meta-analysis showed that $H$. pylori eradication significantly reduces the risk of GC development, in comparison to non-eradication. This evidence was robust, as evidenced by the various sensitivity and other analyses. In addition, these results confirm earlier meta-analyses [12,54]. These significant 


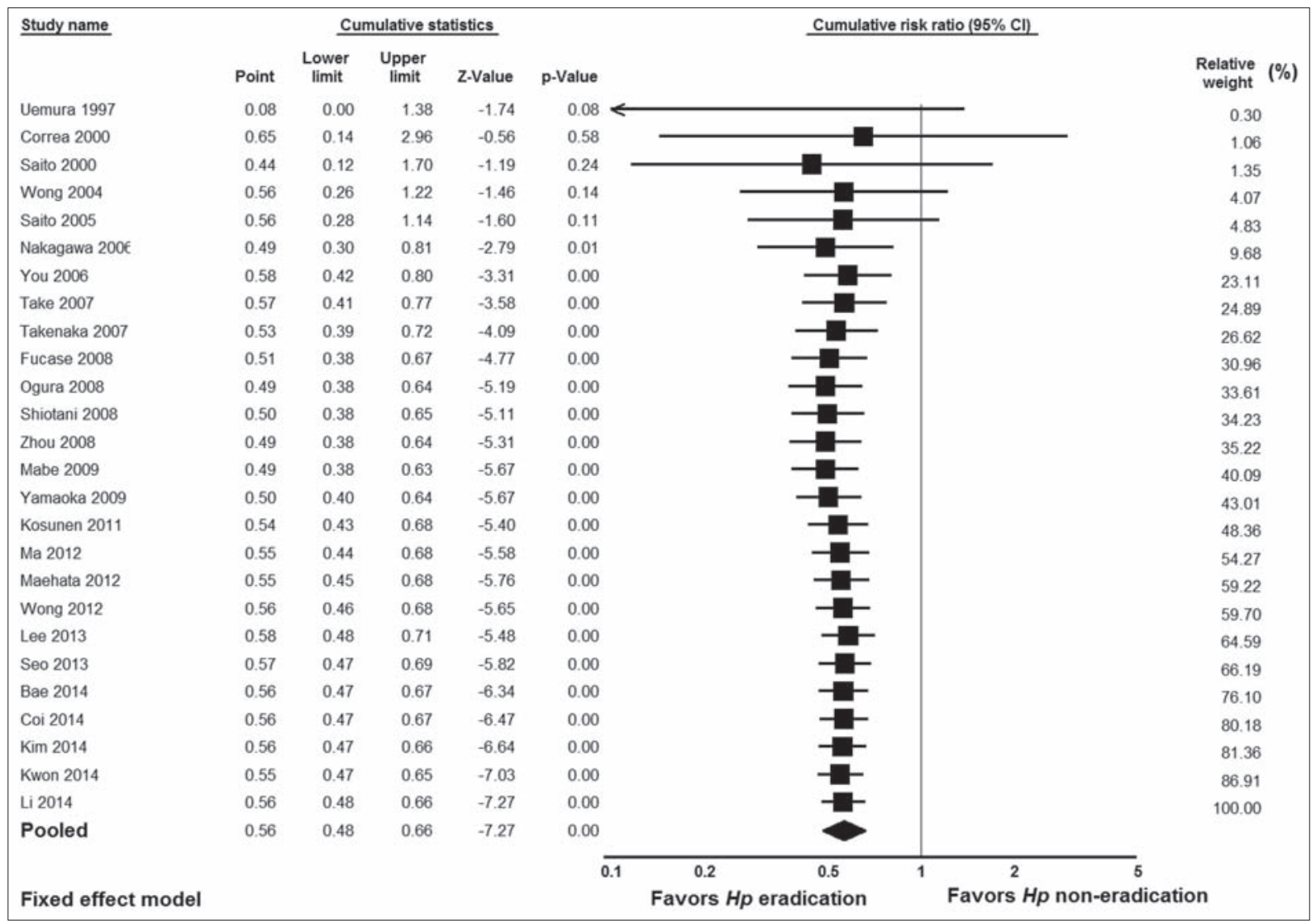

Figure 5 Cumulative meta-analysis of studies ordered by year of publication

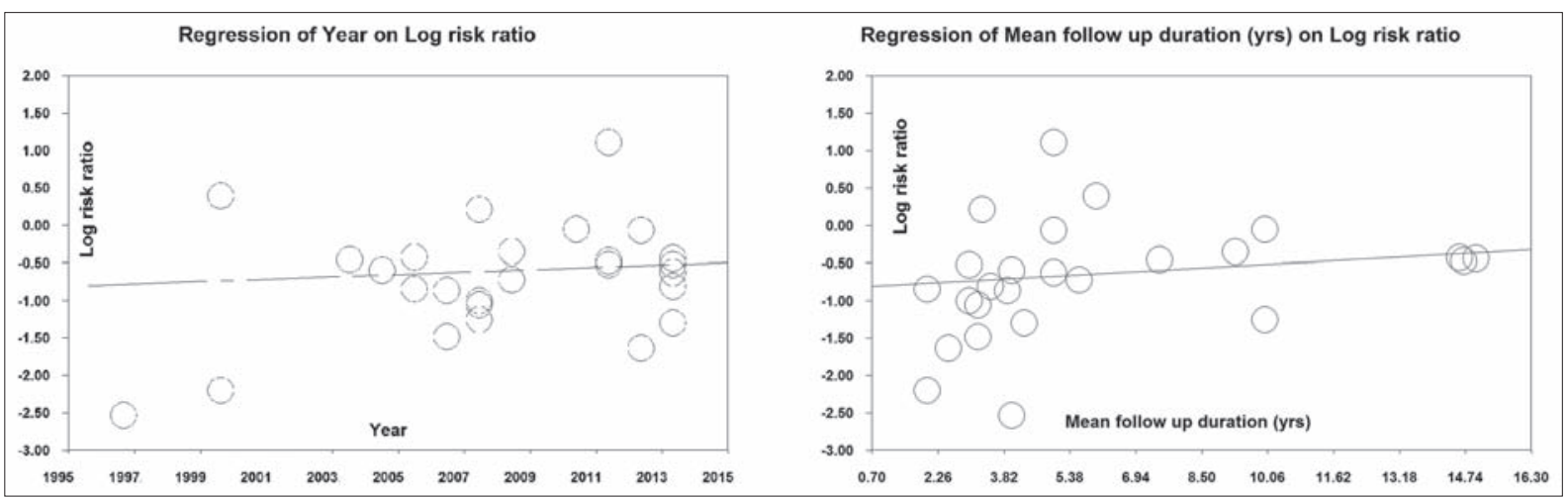

Figure 6 (A) Meta-regression analysis showing regression of publication year on log risk ratio. (B) Meta-regression analysis showing regression of mean follow-up duration on log risk ratio. Circles represent each study in the meta-analysis

results applied for primary prevention and also for secondary prevention, i.e., when evaluating the effect of $H$. pylori treatment on the risk of metachronous GC development after resection of early GC. These results support the notion that mass H. pylori screening and eradication is a viable preventive strategy and should be implemented in high-risk populations, especially in those with an incidence rate higher than 150/100,000 personyears [55]. The number needed to treat varies depending on the GC risk in various populations being studied. Thus, it was calculated that it could be as low as 15 infected men from areas with a high risk of GC, such as China or Japan, in comparison to 250 in infected women from a low-risk area, such as the USA [12].

Some studies $[26,28,31,43,46]$, examined the effect of $H$. pylori eradication on GC risk according to baseline histology. In these studies, baseline histology was stratified into two groups, i.e., a group of subjects with early histological events, namely chronic NAG or AG and a group of subjects with advanced histological events, namely IM or DYS. We meta-analyzed these data, and the results showed that the RR 


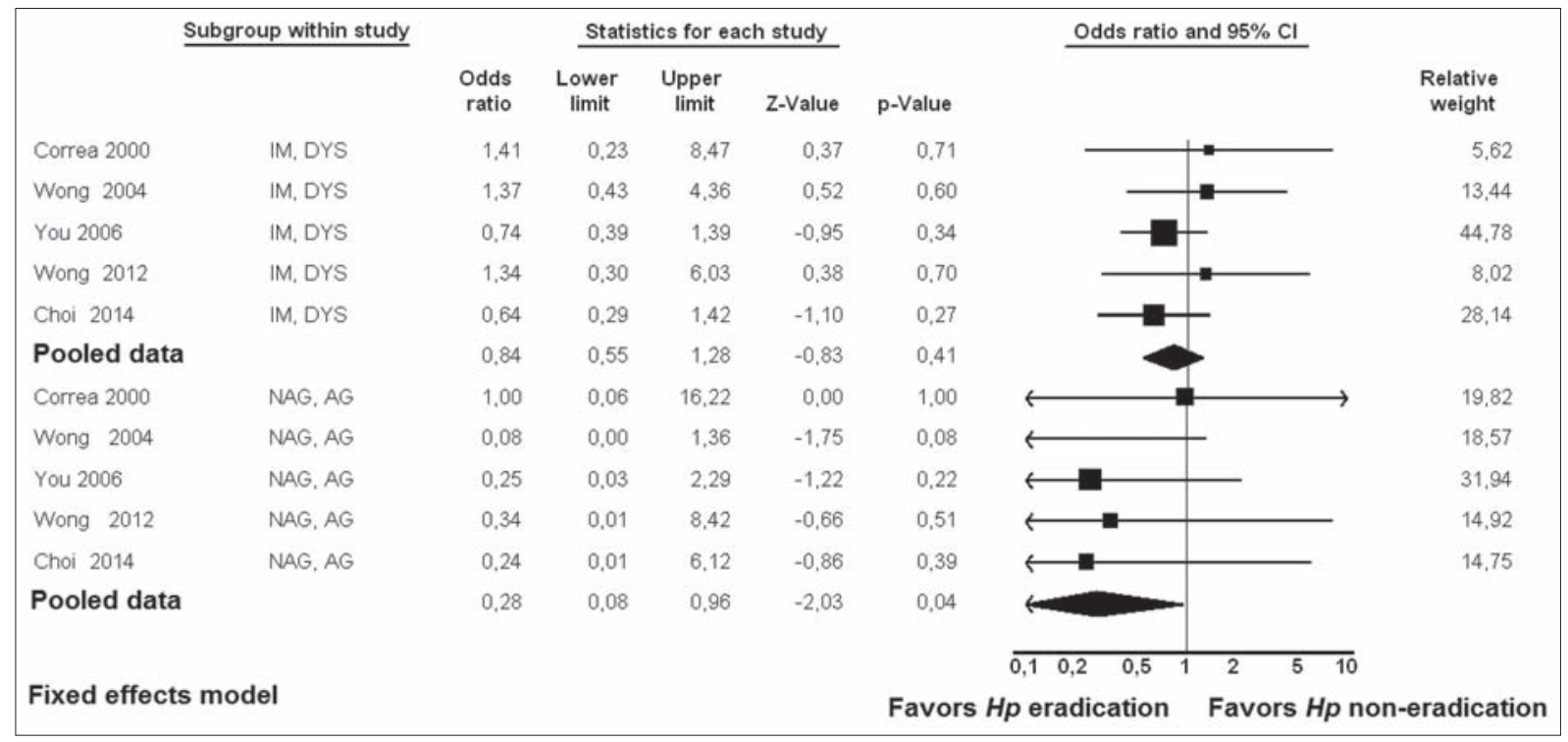

Figure 7 Forest plot showing individual and pooled risk ratios with $95 \%$ confidence intervals in studies comparing gastric cancer risk in Helicobacter pylori ( $\mathrm{Hp}$ )-eradicated patients and in controls, according to baseline histology

NAG, non atrophic gastritis; AG, atrophic gastritis; IM, intestinal metaplasia; DYS, dysplasia

\section{Summary Box}

\section{What is already known:}

- The International Agency for Research on Cancer declared Helicobacter pylori (H. pylori) as a class I human carcinogen and individuals who tested positive for $H$. pylori are at increased risk of developing gastric cancer (GC) compared with uninfected controls

- A growing body of evidence has suggested that H. pylori eradication might prevent GC development

- An earlier meta-analysis reported that H. pylori treatment could reduce the risk of GC in Asians

\section{What the new findings are:}

- This meta-analysis evaluated updated data concerning the effect of $H$. pylori eradication on GC risk and in particular examined the effect of $H$. pylori eradication on GC risk according to baseline histology

- The results support the notion that H. pylori is a significant risk factor for GC and that $H$. pylori eradication is associated with a reduction in the incidence of GC

- H.pylori eradication represents a primary preventive strategy in a subset of subjects with non-atrophic or atrophic gastritis. However, H. pylori eradication in patients who have already developed advanced pre-neoplastic lesions, i.e., intestinal metaplasia or dysplasia, does not prevent GC development
[95\% CI] was significant in the NAG/AG group (0.28 [0.080.96 ], $\mathrm{P}=0.04)$, whereas in the IM/DYS group it was not (0.84 [0.55-1.28], $\mathrm{P}=0.41)$. These results suggest that $H$. pylori eradication represents a primary preventive strategy in a subset of subjects with NAG or AG. In contrast, $H$. pylori eradication in patients who have already developed advanced pre-neoplastic lesions, i.e., IM or DYS, does not prevent GC development. All this supports the notion that IM represents the "point of no return", as was suggested previously [56,57] and was advocated by the recent Maastricht guidelines [58]. If we take into account that IM starts approximately in the fourth decade of life [59], all this could potentially mean that the implementation of $H$. pylori infection screening and treatment could be more effective well before the risk for GC starts increasing [60]. Thus, in Korea it was shown that $H$. pylori eradication might be most effective in the second decade of life [61].

The stability of the results over time, as shown in the cumulative meta-analysis chart and the lack of heterogeneity and publication bias, strengthens the results of this metaanalysis. However, there is a limitation in that 24 of the 26 meta-analyzed studies (92\%) were conducted in far-eastern countries (13 in Japan, 5 in Korea, 5 in China, 1 in Taiwan) and only two were from other parts of the world ( 1 in Colombia, 1 in Finland). Therefore, more studies from non-far-eastern countries are needed to better define the role of $H$. pylori eradication in preventing GC. Additional limitations could be the fact that only studies written in English were included in this meta-analysis and the fact that baseline histology was available only in five studies. The latter stresses the need for more studies that take the baseline histology into account.

In conclusion, the results of this meta-analysis support the notion that $H$. pylori is a significant risk factor for GC. In addition, the results confirmed that $H$. pylori eradication is associated with a reduction in the incidence of GC and 
may therefore be the most viable strategy for GC prevention. However, as these results come mainly from East Asian countries, they must be interpreted with caution for European and North American countries; more studies from these parts of the world are needed to better define the role of $H$. pylori eradication in preventing GC.

\section{References}

1. Ferro A, Peleteiro B, Malvezzi M, et al. Worldwide trends in gastric cancer mortality (1980-2011), with predictions to 2015, and incidence by subtype. Eur J Cancer 2014;50:1330-1344.

2. Bray F, Jemal A, Grey N, Ferlay J, Forman D. Global cancer transitions according to the Human Development Index (20082030): A population-based study. Lancet Oncol 2012;13:790-801.

3. Correa P, Piazuelo MB. Helicobacter pylori infection and gastric adenocarcinoma. US Gastroenterol Hepatol Rev 2011;7:59-64.

4. Correa P. The gastric precancerous process. Cancer Surv 1983;2:437-450.

5. Correa P, Haenszel W, Cuello C, Tannenbaum S, Archer M. A model for gastric cancer epidemiology. Lancet 1975;2:58-60.

6. Nomura A, Stemmermann GN, Chyou PH, Kato I, PerezPerez GI, Blaser MJ. Helicobacter pylori infection and gastric carcinoma among Japanese Americans in Hawaii. $N$ Engl J Med 1991;325:1132-1136.

7. Parsonnet J, Friedman GD, Vandersteen DP, et al. Helicobacter pylori infection and the risk of gastric carcinoma. $N$ Engl J Med 1991;325:1127-1131.

8. Forman D, Newell DG, Fullerton F, et al. Association between infection with Helicobacter pylori and risk of gastric cancer: Evidence from a prospective investigation. BMJ 1991;302:1302-1305.

9. International Agency for Research on Cancer. Schistosomes, liver flukes and Helicobacter pylori. IARC Monogr Eval Carcinog Risks Hum 1994;61:177-241.

10. Machado AM, Figueiredo C, Touati E, et al. Helicobacter pylori infection induces genetic instability of nuclear and mitochondrial DNA in gastric cells. Clin Cancer Res 2009;15:2995-3002.

11. Malfertheiner P, Megraud F, O'Morain CA, et al; European Helicobacter Study Group. Management of Helicobacter pylori infection-the Maastricht IV/Florence Consensus Report. Gut 2012;61:646-664.

12. Ford AC, Forman D, Hunt RH, Yuan Y, Moayyedi P. Helicobacter pylori eradication therapy to prevent gastric cancer in healthy asymptomatic infected individuals: Systematic review and metaanalysis of randomised controlled trials. BMJ 2014;348:g3174.

13. Moher D, Shamseer L, Clarke M, et al; PRISMA-P Group. Preferred reporting items for systematic review and meta-analysis protocols (PRISMA-P) 2015 statement. Syst Rev 2015;4:1.

14. Mantel N, Haenszel W. Statistical aspects of the analysis of data from retrospective studies of disease. J Natl Cancer Inst 1959;22:719-748.

15. DerSimonian R, Laird N. Meta-analysis in clinical trials. Control Clin Trials 1986;7:177-188.

16. Cochran WG. The combination of estimates from different experiments. Biometrics 1954;8:101-129.

17. Higgins JP, Thompson SG. Quantifying heterogeneity in a metaanalysis. Stat Med 2002;21:1539-1558.

18. Sutton AJ, Abrams KR, Jones DR, et al. In: Methods for meta-analysis in medical research. John Wiley \& Sons, Ltd.: New York; 2000.

19. Higgins JP, Thompson SG, Deeks JJ, Altman DG. Measuring inconsistency in meta-analyses. BMJ 2003;327:557-560.

20. Borenstein M, Hedges LV, Higgins JPT, et al. Introduction to metaanalysis. John Wiley \& Sons, Ltd.: New York; 2009.
21. Copas JB, Shi JQ. A sensitivity analysis for publication bias in systematic reviews. Stat Methods Med Res 2001;10:251-265.

22. Begg CB, Mazumdar M. Operating characteristics of a rank correlation test for publication bias. Biometrics 1994;50:1088-1101.

23. Egger M, Davey Smith G, Schneider M, Minder C. Bias in metaanalysis detected by a simple graphical test. BMJ 1997;315:629-634.

24. Duval S, Tweedie R. Trim and fill: A simple funnel-plot-based method of testing and adjusting for publication bias in metaanalysis. Biometrics 2000;56:455-463.

25. Uemura N, Mukai T, Okamoto S, et al. Effect of Helicobacter pylori eradication on subsequent development of cancer after endoscopic resection of early gastric cancer. Cancer Epidemiol Biomarkers Prev 1997;6:639-642.

26. Correa P, Fontham ET, Bravo JC, et al. Chemoprevention of gastric dysplasia: Randomized trial of antioxidant supplements and antiHelicobacter pylori therapy. J Natl Cancer Inst 2000;92:1881-1888.

27. Saito K, Arai K, Mori M, Kobayashi R, Ohki I. Effect of Helicobacter pylori eradication on malignant transformation of gastric adenoma. Gastrointest Endosc 2000;52:27-32.

28. Wong BC, Lam SK, Wong WM, et al; China Gastric Cancer Study Group. Helicobacter pylori eradication to prevent gastric cancer in a high-risk region of China: A randomized controlled trial. JAMA 2004;291:187-194.

29. Saito D, Boku N, Fujioka T, et al. Impact of $H$. pylori eradication on gastric cancer prevention: Endoscopic results of the Japanese Intervention Trial. Gastroenterology 2005;128:A4.

30. Nakagawa S, Asaka M, Kato M, et al. Helicobacter pylori eradication and metachronous gastric cancer after endoscopic mucosal resection of early gastric cancer. Aliment Pharmacol Ther 2006;24(Suppl 4):214-218.

31. You WC, Brown LM, Zhang L, et al. Randomized double-blind factorial trial of three treatments to reduce the prevalence of precancerous gastric lesions. J Natl Cancer Inst 2006;98:974-983.

32. Take S, Mizuno M, Ishiki K, et al. Baseline gastric mucosal atrophy is a risk factor associated with the development of gastric cancer after Helicobacter pylori eradication therapy in patients with peptic ulcer diseases. J Gastroenterol 2007;42(Suppl 17):21-27.

33. Takenaka R, Okada H, Kato J, et al. Helicobacter pylori eradication reduced the incidence of gastric cancer, especially of the intestinal type. Aliment Pharmacol Ther 2007;25:805-812.

34. Fukase K, Kato M, Kikuchi S, et al; Japan Gast Study Group. Effect of eradication of Helicobacter pylori on incidence of metachronous gastric carcinoma after endoscopic resection of early gastric cancer: An open-label, randomised controlled trial. Lancet 2008;372:392-397.

35. Ogura K, Hirata Y, Yanai A, et al. The effect of Helicobacter pylori eradication on reducing the incidence of gastric cancer. J Clin Gastroenterol 2008;42:279-283.

36. Shiotani A, Uedo $\mathrm{N}$, Iishi $\mathrm{H}$, et al. Predictive factors for metachronous gastric cancer in high-risk patients after successful Helicobacter pylori eradication. Digestion 2008;78:113-119.

37. Zhou L. Ten-year follow-up study on the incidence of gastric cancer and the pathological changes of gastric mucosa after $H$. pylori eradication in China. Gastroenterology 2008;134:A233.

38. Mabe K, Takahashi M, Oizumi H, et al. Does Helicobacter pylori eradication therapy for peptic ulcer prevent gastric cancer? World $J$ Gastroenterol 2009;15:4290-4297.

39. Yanaoka K, Oka M, Ohata H, et al. Eradication of Helicobacter pylori prevents cancer development in subjects with mild gastric atrophy identified by serum pepsinogen levels. Int J Cancer 2009;125:26972703.

40. Kosunen TU, Pukkala E, Sarna S, et al. Gastric cancers in Finnish patients after cure of Helicobacter pylori infection: A cohort study. Int J Cancer 2011;128:433-439.

41. Ma JL, Zhang L, Brown LM, et al. Fifteen-year effects of Helicobacter 
pylori, garlic, and vitamin treatments on gastric cancer incidence and mortality. J Natl Cancer Inst 2012;104:488-492.

42. Maehata Y, Nakamura S, Fujisawa K, et al. Long-term effect of Helicobacter pylori eradication on the development of metachronous gastric cancer after endoscopic resection of early gastric cancer. Gastrointest Endosc 2012;75:39-46.

43. Wong BC, Zhang L, Ma JL, et al. Effects of selective COX-2 inhibitor and Helicobacter pylori eradication on precancerous gastric lesions. Gut 2012;61:812-818.

44. Seo JY, Lee DH, Cho Y, et al. Eradication of Helicobacter pylori reduces metachronous gastric cancer after endoscopic resection of early gastric cancer. Hepatogastroenterology 2013;60:776-780.

45. Bae SE, Jung HY, Kang J, et al. Effect of Helicobacter pylori eradication on metachronous recurrence after endoscopic resection of gastric neoplasm. Am J Gastroenterol 2014;109:60-67.

46. Choi J, Kim SG, Yoon H, et al. Eradication of Helicobacter pylori after endoscopic resection of gastric tumors does not reduce incidence of metachronous gastric carcinoma. Clin Gastroenterol Hepatol 2014;12:793-800.

47. Kim YI, Choi IJ, Kook MC, et al. The association between Helicobacter pylori status and incidence of metachronous gastric cancer after endoscopic resection of early gastric cancer. Helicobacter 2014;19:194-201.

48. Kwon YH, Heo J, Lee HS, Cho CM, Jeon SW. Failure of Helicobacter pylori eradication and age are independent risk factors for recurrent neoplasia after endoscopic resection of early gastric cancer in 283 patients. Aliment Pharmacol Ther 2014;39:609-618.

49. Lee YC, Chen TH, Chiu HM, et al. The benefit of mass eradication of Helicobacter pylori infection: A community-based study of gastric cancer prevention. Gut 2013;62:676-682.

50. Li WQ, Ma JL, Zhang L, et al. Effects of Helicobacter pylori treatment on gastric cancer incidence and mortality in subgroups. J Natl Cancer Inst 2014;106:dju0116. doi: 10.1093/jnci/dju116.

51. Houghton J, Wang TC. Helicobacter pylori and gastric cancer: A new paradigm for inflammation-associated epithelial cancers.
Gastroenterology 2005;128:1567-1578.

52. Uemura N, Okamoto S, Yamamoto S, et al. Helicobacter pylori infection and the development of gastric cancer. $N$ Engl J Med 2001;345:784-789.

53. Correa P. The epidemiology of gastric cancer. World J Surg 1991;15:228-234.

54. Fuccio L, Zagari RM, Minardi ME, Bazzoli F. Systematic review: Helicobacter pylori eradication for the prevention of gastric cancer. Aliment Pharmacol Ther 2007;25:133-141.

55. Lee YC, Chiang TH, Chou CK, et al. Association between Helicobacter pylori eradication and gastric cancer incidence: A systematic review and meta-analysis. Gastroenterology 2016;150:1113-1124.

56. Rokkas T, Pistiolas D, Sechopoulos P, Robotis I, Margantinis G. The long-term impact of Helicobacter pylori eradication on gastric histology: A systematic review and meta-analysis. Helicobacter 2007;12(Suppl 2):32-38.

57. Wang J, Xu L, Shi R, et al. Gastric atrophy and intestinal metaplasia before and after Helicobacter pylori eradication: A meta-analysis. Digestion 2011;83:253-260.

58. Malfertheiner P, Megraud F, O'Morain CA, et al; European Helicobacter and Microbiota Study Group and Consensus panel. Management of Helicobacter pylori infection-the Maastricht V/ Florence Consensus Report. Gut 2017;66:6-30.

59. Kim N, Park YS, Cho SI, et al. Prevalence and risk factors of atrophic gastritis and intestinal metaplasia in a Korean population without significant gastroduodenal disease. Helicobacter 2008;13:245-255.

60. Liu CY, Wu CY, Lin JT, Lee YC, Yen AM, Chen TH. Multistate and multifactorial progression of gastric cancer: Results from community-based mass screening for gastric cancer. J Med Screen 2006;13(Suppl 1):S2-S5.

61. Shin CM, Kim N, Yang HJ, et al. Stomach cancer risk in gastric cancer relatives: Interaction between Helicobacter pylori infection and family history of gastric cancer for the risk of stomach cancer. J Clin Gastroenterol 2010;44:e34-e39. 